Thompson, R. Localization of the "visual memory system" in the white rat. Journal of Comparative \& Physiological Psychology, 1969, 69, 1-29.

Thompson, R. Introducing subcortical lesions by electrolytic methods. In R. D. Myers (Ed.), Methods in psychobiology. New York: Academic Press, 1971.

Thompson, R. Localization of the "maze memory system" in the white rat. Physiological Psychology, 1974, in press.

Thompson, R., \& Bryant, J. H. Memory as affected by activity of the relevant receptor. Psychological Reports, 1955, 1, 393-400.

Thompson, R., Malin, C. F., \& Hawkins, W. F. Effect of subcortical lesions on retention of a kinesthetic discrimination habit. Experimental Neurology, 1961, 3, 367-374.

Thompson, R. \& Massopust, L. C. The effect of subcortical lesions on retention of a brightness discrimination in rats. Journal of Comparative \& Physiological Psychology, 1960, 53, 488-496.

Thompson, R., \& Thorne, B. M. Brainstem reticular formation lesions: Amnestic effects on learned habits in the rat. Physiological Psychology, 1973, 1, 61-70.

(Received for publication January 28, 1974.)

Bulletin of the Psychonomic Society

1974, Vol. 3 (4), 295-297

\title{
Effects of stimulus duration on temporal facilitation*
}

\author{
HALSEY H. MATTESON, JOEL H. LEWIS $\dagger$, and WILLIAM P. DUNLAP \\ Tulane University, New Orleans, Louisiana 70118
}

\begin{abstract}
High-luminance surrounds can reduce perceptual latency (temporal facilitation). Test stimuli of four durations (5 msec, $100 \mathrm{msec}$, 5-sec onset, and 5-sec offset) were judged against comparison stimuli of several durations. Temporal facilitation of almost $100 \mathrm{msec}$ was obtained with the 5-msec test regardless of the comparison used. With $100 \mathrm{msec}$ and 5 -sec onset test stimuli, temporal facilitation was less and occured only with identical test and comparison stimuli. Offset latencies were shorter than onset latencies, and only one $\mathrm{S}$ showed temporal facilitation with offset test stimuli. Results were discussed in terms of the temporal course of brightness.
\end{abstract}

An intense surround can shorten perceptual latency of a stimulus by as much as $100 \mathrm{msec}$, compared to latency on a dark background (temporal facilitation). Using the perceived-order method, Matteson $(1970,1971)$ found temporal facilitation with brief $(5 \mathrm{msec})$ test stimuli. Studies reporting similar latency reduction with the Pulfrich pendulum (references in Matteson, 1971) and the Hess effect (Prestrude \& Baker, 1971) used narrow, rapidly moving lines, which produce brief stimulation of a given retinal area. With longer-duration test stimuli, Bartlett and MacLeod (1954) and Hansteen (1971) found that intense backgrounds increased latency. One

*This research was supported by Grant EY-00021 from the National Eye Institute to the first author.

†Present address: Department of Psychology, Kearney State College, Kearney, Nebraska 68847. possible explanation of this discrepancy is that temporal facilitation might occur only with brief test stimuli.

It has been suggested previously (Matteson, 1971) that temporal facilitation might be due to suppression of visual persistence by light adaptation. Piéron's (1934) hypothetical brightness-vs-time curve reaches an initial peak ("on" firing), levels off to a somewhat lower stable level for the remainder of stimulus duration, and then fades out after stimulus offset (persistence). Contrast data (Heinemann, 1955) show that a surround reduces brightness of weak stimuli more than it reduces brightness of intense stimuli. If contrast results are applied to Piéron's curve, an intense surround should produce the smallest reduction of the initial peak ("on" response), slightly more reduction of the lower brightness after the initial peak, and greatest reduction 


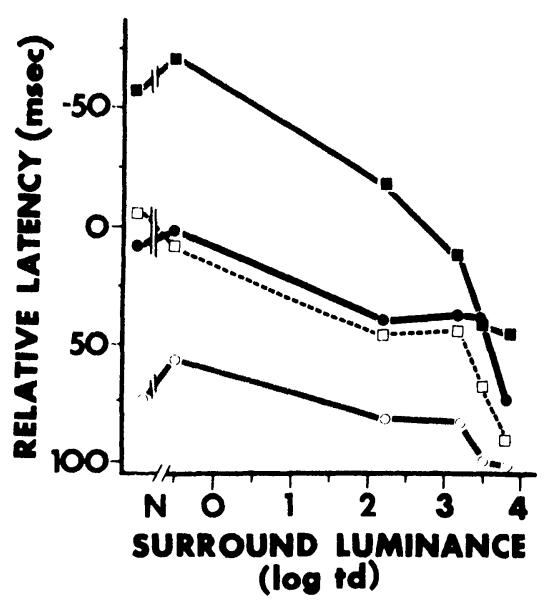

Fig. 1. Mean relative latency as a function of surround luminance with 5 -msec test and comparison stimuli (open squares), 5-m sec test and 5-sec off set comparison (filled squares), 5-sec of fset test stimulus and 5-msec comparison (open circles), and 5 -sec offset test and comparison stimuli (filled circles). $\mathrm{N}$ indicates the no-surround control condition.

of residual brightness after stimulus offset (persistence). With an intense surround (test just above increment threshold), the initial peak could be the only remaining neural response. The following predictions can be made with the rationale given above: (1) Since brief $(5 \mathrm{msec})$ stimuli involve a mixed onset and offset response (Ikeda \& Boynton, 1965) followed by persistence, they should result in greatest temporal facilitation. (2) With moderate test duration $(100 \mathrm{msec})$, persistence should be more widely separated from "on" responses, thus less facilitation would be expected. (3) With long test duration $(5 \mathrm{sec})$, onset clearly precedes offset, so persistence should not affect latency judgments; therefore, no facilitation would be expected unless $S$ responded to stable activity following stimulus onset as well as the initial peak.

Suppression of persistence also has implications for offset stimuli. Since the retina is light adapted at offset of a long-duration test, it can be predicted that: (1) offset latencies will usually be shorter than onset latencies, and (2) with an intense test, a surround should have little effect on latency.

\section{METHOD}

The three-channel Maxwellian-view optical system was described by Matteson (1969), and procedures were identical to those of Matteson (1970). With the perceived-order method, the interval between test and comparison stimuli is varied to obtain subjective simultaneity. Relative latency was defined as test occurrence minus comparison occurence (a positive value indicates that test response was faster than comparison response). Points of subjective simultaneity were obtained with two intertwined staircase series. Each session started with 20-min dark adaptation, and measures were made at two surround luminances in a session. The Ss (H.M. and J.L., aged 34 and 24) had normal acuity with eyeglasses.

Test and comparison stimuli were 30 -min disks. The annular surround was $33 \mathrm{~min}$ inner diam and $45 \mathrm{~min}$ outer diam. Test and surround were concentric and centered $3 \mathrm{deg} 30 \mathrm{~min}$ above the fixation point in the right eye. The comparison was $3 \mathrm{deg} 30 \mathrm{~min}$ below fixation in the left eye. The surround was continuously illuminated during observations. The six surround luminances ranged from 0 to 6,400 trolands (td). The lowest surround $(.3 \mathrm{td})$ was no more than $.4 \mathrm{log}$ above absolute threshold. Three replications were conducted.

The four test-stimulus conditions were $5 \mathrm{msec}, 100 \mathrm{msec}$, onset of a 5-sec flash, and offset of a 5-sec flash. With 5-msec and $100-\mathrm{msec}$ durations, Ss were unable to distinguish offset from onset: Observations in which $\mathrm{S}$ judged test offset gave the same latencies as onset judgments. The 5-msec comparison stimulus was $100 \mathrm{td}$. The highest surround luminance reduced test brightness to approximately $.3 \mathrm{log}$ above increment threshold. Test luminance was $100 \mathrm{td}$ with the 5 -msec test and 17 td with 100 -msec and 5-sec tests.

Since perceived-order judgments can be difficult when test and comparison durations are different (Lewis et al, 1972), subsequent experiments were conducted with identical test and comparison stimuli: (1) A 100-msec test was judged against a 100-msec comparison. (2) Onset of a 5-sec test was judged against a 5-sec onset comparison. (3) Offset of a 5-sec test was judged against offset of a 5-sec comparison. (4) A 5-msec test was also judged against offset of a 5 -sec stimulus, a stimulus which was quite different from the test. In these four experiments, comparison luminance was $17 \mathrm{td}$, a level which made comparison brightness equal to that of the $5 \mathrm{msec}, 100 \mathrm{td}$ comparison used in the initial experiment.

\section{RESULTS AND DISCUSSION}

Appreciable temporal facilitation was obtained with 5-msec test and comparison stimuli. The latency curve (open squares, Fig. 1) was similar to previous curves (Matteson, 1970, 1971). There was a small latency reduction between no surround and the weakest surround, moderate reduction until surround and test luminances were about equal (third point from left), and large reduction when surround luminance exceeded test luminance (last 3 points). Facilitation with the $5-\mathrm{msec}$ test and 5-sec offset comparison (Fig. 1, filled squares) was just as large as that obtained with 5 -msec test and comparison stimuli. In Table 1, latency reduction between no surround and the lowest surround is shown in the first column, and latency reduction between lowest and highest surrounds is given in the second column. J.L.'s latencies averaged $63.3 \mathrm{msec}$ longer than H.M.'s latencies, but between-Ss agreement was close with the 5-msec test.

With 100-msec and 5-sec onset tests judged against the 5 -msec comparison, temporal facilitation was less (Table 1, top). The small latency reduction between no surround and the weakest surround was approximately equal for all onset stimuli, but latency reduction with the three most intense surrounds and 100-msec and 5-sec onset tests was not as large as with the 5 -msec test. As can be seen in Table 1, J.L. had more facilitation with 100 -msec test and comparison stimuli than with the 100 -msec test judged against the 5-msec comparison, and facilitation with 5 -sec onset test and comparison stimuli was much larger than with $5-\mathrm{sec}$ onset test and 5-msec 
comparison stimuli. H.M. showed almost no facilitation with the 5 -sec onset test and a moderate amount with the 100-msec test, regardless of the comparison stimulus used. As was predicted, facilitation with the $100-\mathrm{msec}$ test was less than with the $5-\mathrm{msec}$ test, but the prediction of no facilitation with the 5-sec onset test was not supported. Since one $\mathrm{S}$ showed facilitation with the 5-sec onset test, and he could not have responded to events after stimulus offset, persistence is not a necessary condition for temporal facilitation. It is possible that intense surrounds could inhibit activity after the "on" burst (the middle of Piéron's curve), leaving onset activity as the only event mediating latency judgments.

Previous studies showing temporal facilitation used brief stimuli (Matteson, 1970, 1971). With long-duration tests $(2,500$ and $500 \mathrm{msec}$, respectively), Hansteen (1971) and Bartlett and MacLeod (1954) found increased latency with intense backgrounds. Since preliminary reaction time (RT) measures from this laboratory showed the same increase that Bartlett and MacLeod found with RT, the difference between the present results and their results might be due to differences between RT and the perceived-order method. Hansteen's perceived-order results are not explained by the present findings; however, the present study showed inconsistencies between Ss only with long-duration test stimuli.

Table 1

Latency Reduction Between No-Surround Control Condition and Lowest Luminance (.3 td) Surround (LS-NS), Latency Reduction Between Lowest Luminance and Highest Luminance (6400 td) Surround (HS-LS), and Latency With No Surround for Ss H.M. and J.L.

\begin{tabular}{|c|c|c|c|c|c|}
\hline Test & $\begin{array}{l}\text { Compar- } \\
\text { ison }\end{array}$ & $S$ & LS-NS & HS-LS & $\begin{array}{l}\text { Latency } \\
\text { With No } \\
\text { Surround }\end{array}$ \\
\hline $\begin{array}{c}5 \\
\mathrm{msec}\end{array}$ & $\begin{array}{c}5 \\
\mathrm{msec}\end{array}$ & $\begin{array}{l}\text { H.M. } \\
\text { J.L. }\end{array}$ & $\begin{array}{l}15.1 \\
16.8\end{array}$ & $\begin{array}{l}81.4 \dagger \\
84.1 \dagger\end{array}$ & $\begin{array}{r}23.0 \\
-34.3\end{array}$ \\
\hline $\begin{array}{l}100 \\
\mathrm{msec}\end{array}$ & $\begin{array}{c}5 \\
\mathrm{msec}\end{array}$ & $\begin{array}{l}\text { H.M. } \\
\text { J.L. }\end{array}$ & $\begin{array}{l}16.2 \\
33.9\end{array}$ & $\begin{array}{l}50.8 \dagger \\
11.0\end{array}$ & $\begin{array}{r}15.3 \\
-56.1\end{array}$ \\
\hline $\begin{array}{l}\text { 5-sec } \\
\text { onset }\end{array}$ & $\begin{array}{c}5 \\
\text { msec }\end{array}$ & $\begin{array}{l}\text { H.M. } \\
\text { J.L. }\end{array}$ & $\begin{array}{l}25.8 \\
20.2\end{array}$ & $\begin{array}{l}18.9 \\
31.9 *\end{array}$ & $\begin{array}{r}24.0 \\
-29.7\end{array}$ \\
\hline $\begin{array}{l}100 \\
\mathrm{msec}\end{array}$ & $\begin{array}{l}100 \\
\text { msec }\end{array}$ & $\begin{array}{l}\text { H.M. } \\
\text { J.L. }\end{array}$ & $\begin{array}{l}29.8 \\
22.7\end{array}$ & $\begin{array}{l}63.3^{*} \\
41.1 \dagger\end{array}$ & $\begin{array}{r}33.8 \\
-27.5\end{array}$ \\
\hline $\begin{array}{l}5 \text {-sec } \\
\text { onset }\end{array}$ & $\begin{array}{l}5-\mathrm{sec} \\
\text { onset }\end{array}$ & $\begin{array}{l}\text { H.M. } \\
\text { J.L. }\end{array}$ & $\begin{array}{r}30.0 \\
-1.8\end{array}$ & $\begin{array}{l}16.0 \\
82.3 \dagger\end{array}$ & $\begin{array}{r}-2.7 \\
-27.9\end{array}$ \\
\hline $\begin{array}{l}5 \text {-sec } \\
\text { offset }\end{array}$ & $\begin{array}{c}5 \\
\mathrm{msec}\end{array}$ & $\begin{array}{l}\text { H.M. } \\
\text { J.L. }\end{array}$ & $\begin{array}{l}-13.3 \\
-25.0\end{array}$ & $\begin{array}{l}63.0^{*} \\
30.6\end{array}$ & $\begin{array}{l}80.3 \\
67.3\end{array}$ \\
\hline $\begin{array}{l}5 \text {-sec } \\
\text { offset }\end{array}$ & $\begin{array}{l}5 \text {-sec } \\
\text { offset }\end{array}$ & $\begin{array}{l}\text { H.M. } \\
\text { J.L. }\end{array}$ & $\begin{array}{r}4.8 \\
-16.4\end{array}$ & $\begin{array}{c}109.0 \dagger \\
32.3\end{array}$ & $\begin{array}{r}31.0 \\
-15.4\end{array}$ \\
\hline $\begin{array}{c}5 \\
\mathrm{msec}\end{array}$ & $\begin{array}{l}\text { 5-sec } \\
\text { offset }\end{array}$ & $\begin{array}{l}\text { H.M. } \\
\text { J.L. }\end{array}$ & $\begin{array}{r}-17.1 \\
-5.1 \\
\end{array}$ & $\begin{array}{l}115.6 \dagger \\
115.2 \dagger\end{array}$ & $\begin{array}{r}-8.1 \\
-109.7 \\
\end{array}$ \\
\hline
\end{tabular}

*Main effect of surround luminance significant at .05 level in a treatments by replications factorial analysis of variance. tSignificant at .01 level.
There were two indications that offset latencies were shorter than onset latencies: (1) With no surround, latency of the $5-\mathrm{sec}$ offset test was shorter than latencies of all onset stimuli (Table 1, third column). (2) With both $5 \mathrm{msec}$ and $5 \mathrm{sec}$ offset tests, latencies were longer with the 5-sec offset comparison (filled symbols, Fig. 1) than with the 5-msec comparison (open symbols). Latencies were longer with the offset comparison because they were measured relative to a shorter-latency comparison. The shorter offset latencies agree with previous studies (Hansteen, 1971; Lewis et al, 1972) and were predicted on the basis that the test stimulus causes light adaptation.

The shape of the mean offset latency curve obtained with the offset comparison (Fig. 1, filled circles) was similar to the curve obtained with the 5-msec comparison (open circles). H.M. showed appreciable facilitation with offset tests, but J.L. showed little (Table 1 , bottom). No facilitation was predicted with offset tests, since the test causes light adaptation. Differences between Ss may simply reflect differing susceptibility to light adaptation, because the 17-td test was dim.

With onset tests, there was a small reduction of latency between no surround and the weakest surround, but there was a slight increase with offset stimuli (Table 1, first column). The initial latency reduction with onset stimuli might be due to reduction of uncertainty about test-stimulus position by the dim surround. Initial latency increases with offsets cannot be explained in the same way, and it is puzzling why this occurred with onset tests and offset comparisons as well as with offset tests.

\section{REFERENCES}

Bartlett, N. R., \& MacLeod, S. Effects of flash and field luminance on human reaction time. Journal of the Optical Society of America, 1954, 44, 306-311.

Hansteen, R. W. Visual latency as a function of stimulus onset offset, and background luminance. Journal of the Optical Society of America, 1971, 61, 1190-1195.

Heinemann, E. G. Simultaneous brightness induction as a function of inducing- and test-field luminances. Journal of Experimental Psychology, 1955, 50, 89-96.

Ikeda, M., \& Boynton, R. M. Negative flashes, positive flashes, and flicker examined by increment threshold technique. Journal of the Optical Society of America, 1965, 55, 560-566.

Lewis, J. H., Dunlap, W. P., \& Matteson, H. H. Perceptual latency as a function of stimulus onset and offset and retinal location. Vision Research, 1972, 12, 1725-1731.

Matteson, H. H. Effects of surround size and luminance on metacontrast. Journal of the Optical Society of America, $1969,59,1461-1468$.

Matteson, H. H. Effects of surround luminance on perceptual latency. Journal of the Optical Society of America, 1970, 60, 1125-1131.

Matteson, H. H. Effects of surround luminance on perceptual latency in the fovea. Journal of the Optical Society of America, 1971, 61, 1169-1172.

Piéron, P. H. L'evanouissement de la sensation lumineuse. L'Anneé Psychologique, 1934, 35, 1-49.

Prestrude, A. M., \& Baker, H. D. Light adaptation and visual latency. Vision Research, 1971, 11, 363-369.

(Received for publication January 24, 1974.) 